\title{
Influence of detection of pretreatment cytogenetic abnormalities on first complete remission and survival in adult acute lymphoblastic leukemia
}

\author{
Erişkin akut lenfoblastik lösemide ilk tam remisyon ve sağkalım üzerinde \\ tedavi öncesi sitogenetik anomalilerin saptanmasının önemi
}

\author{
Milena Georgieva Velizarovaㄹ, Evgueniy A. Hadjiev², Kamelia V. Alexandrova², \\ Ivanka I. Dimova ${ }^{3}$, Draga I. Toncheva ${ }^{3}$, Nadya E. Dimitrova ${ }^{4}$ \\ 1Department of Clinical Laboratory and Clinical of Immunology, Alexandrovska University Hospital, Sofia, Bulgaria \\ ${ }^{2}$ Clinic of Hematology, Alexandrovska University Hospital, Sofia, Bulgaria \\ ${ }^{3}$ Department of Medical Genetics, Medical University, Sofia, Bulgaria \\ ${ }^{4}$ National Oncological Hospital, Bulgarian National Cancer Registry, Sofia, Bulgaria
}

\begin{abstract}
Objective: Treatment of acute lymphoblastic leukemia (ALL) in adults focuses on the initial assessment of the prognostic relevant cytogenetic features as well as a response-guided therapy based on molecular data. We examined the importance of molecular-cytogenetic abnormalities for complete remission (CR) rates and the overall survival (OS) in adult ALLs.

Materials and Methods: Conventional cytogenetics and fluorescence in situ hybridization were performed on bone marrow cells from 33 newly-diagnosed ALL adults. Two karyotype categories [standard- risk group- normal karyotype, hyperdiplody and other structural aberrations, and high-risk group-t(11q23)/MLL, t(9;22)/bcr-abl, t $(1 ; 19), t(8 ; 14), C-M Y C$ and complex karyotype] and the biologically and clinically relevant ALL ploidy subgroups were prospectively defined.

Results: Chromosomal abnormalities were found in $\mathbf{5 2 \%}$ of the cases with a high rate of poor-risk translocations - $t(9 ; 22), t(8 q 24), t(11 q 23), t(1 ; 19)$. The total $C R$ rate was $67 \%$ and the median time for achievement 2.33 months. Male sex, an age below 35 years and the absence of high risk translocations might have contributed to the high CR rates. Female patients, hyperdiplody, low white blood cells (WBC), and random cytogenetic aberrations had the longest OS. OS, 3- and 5-years survival periods were significantly shorter for poor-risk than standard risk group $(p=.015, p=.001$ and $p=.005$, respectively).

Conclusion: This study emphasizes the lack of influence of cytogenetic aberrations on the CR and the time to achieve CR. However, our observations show that these aberrations are an independent prognostic factor in adult ALL - they allow predicting therapy resistance and the OS time after intense treatment. (Turk J Hematol 2011; 28: 176-85)
\end{abstract}

Key words: Adult acute lymphoblastic leukemia, complete remission, karyotype, overall survival 


\section{Özet}

Amaç: Erişkinlerde akut lenfoblastik lösemi (ALL) tedavisinde prognostik açıdan önemli sitogenetik özelliklerin değerlendirmesi ve bunun yanı sıra moleküler verilere göre yanıt yönlendirmeli tedaviye odaklanılmaktadır. Erişkin ALL'de tam yanıt (TR) oranları ve genel sağkalım (GS) için moleküler sitogenetik anomalilerin önemi incelenmiştir.

Yöntemler ve Gereçler: Yeni tanı alan 33 erişkin ALL'li hastadan alınan kemik iliği hücreleri klasik sitogenetik ve floresans in situ hibridizasyon yöntemi ile incelendi. Olgular iki karyotip grubuna [standart-risk grubu- normal karyotip, hiperdiplodi ve diğer yapısal aberasyonlar ve yüksek-risk grubu - t(11q23)/ MLL, $t(9 ; 22) / b c r-a b l, t(1 ; 19), t(8 ; 14), C-M Y C$ ve kompleks karyotip] ve biyolojik / klinik açıdan önemli ALL ploidi alt gruplarının ayrılarak tanımlanmıştır.

Bulgular: Kötü riskli t(9;22), t(8q24), t(11q23), t(1;19) kromozom anomalileri yüksek orandadır, olguların \%52'sinde belirlenmiştir. Toplam tam yanıt (TR) oranı \%67 olup TR sağlanana kadar geçen ortalama süre 2.33 aydır. Erkek cinsiyeti, 35 'in altındaki yaş ve yüksek risk translokasyonlarının bulunmaması yüksek TR oranlarına ulaşılmasında katkıda bulunmuş olabilir. Kadın hastalar, hiperdiplodi, düsük lökosit sayısı (WBC) ve random sitogenetik anomaliler de en uzun GS gözlenmiştir. Üç ve beş yıllık sağkalım aralıklarında, GS, standart riskli gruba göre düşük riskli grupta anlamlı şekilde daha kısadır (sırasiyla $p=.015, p=.001$ ve $p=.005$ ).

Sonuç: Bu çalışmada sitogenetik aberasyonların TR oranı ve TR sağlanana kadar geçen süre üzerinde etkisinin bulunmadığı vurgulanmaktadır. Bununla birlikte gözlemlerimiz bu aberasyonların erişkin ALL'de bağımsız bir prognostik faktör olduğunu göstermektedir. Bu bulgular tedaviye direncin ve yoğun tedavi sonrası GS süresinin öngörülmesine izin verir. (Turk J Hematol 2011; 28: 176-85)

Anahtar kelimeler: Erişkin akut lenfoblastik lösemi, tam remisyon, karyotip, genel sağkalım

\section{Introduction}

Acute lymphoblastic leukemia (ALL) is a fairly uncommon disease in adults and is associated with a poor prognosis. The treatment of adult ALL is based on the initial assessment of relevant prognostic molecular-cytogenetic features and responseguided therapy based on molecular data. In more than $50 \%$ of adult ALL patients clonal chromosomal abnormalities that deregulate candidate oncogenes or transcription factors by introducing a heterologous promoter or enhancer are observed [1-3]. Altered cell cycle progression or upregulated tyrosine kinase activity are other important mechanisms in ALL [2-5]. Most translocations can lead to generation of fusion genes that translate into chimeric oncogenic proteins, providing targets for novel therapeutic agents. The most important prognostic factors in ALL are cytogenetic abnormalities, the time to achieve complete remission (CR), the initial leukocyte count, age, and immunologic subtype [4-8]. Cytogenetic abnormalities observed in ALL patients are among the most important independent prognostic variables that predict outcome; $[5,6,9]$ ploidy and translocations are correlated with prognosis [10,11]

ALL is heterogeneous and can be subtyped based on chromosomal, immunophenotypic, and molecular criteria. The prognostic implications of different ALL subtypes strongly influence the choice of treatment in adults $[5,6,12]$. Many patients with T-cell ALL can be cured with chemotherapy alone. In contrast, patients with early B-lineage ALL and certain chromosomal abnormalities, especially the Philadelphia chromosome, do not have durable responses to chemotherapy and should undergo bone marrow transplantation [13,14].

The aim of the present study was to determine the frequency and prognostic significance of molecular-cytogenetic abnormalities, and to ascertain whether or not karyotype is a significant prognostic factor in adult ALL patients, independent of new intensive chemotherapy regimens and initial clinical characteristics.

\section{Material and Methods}

\section{Study design}

Patients

The study included 33 patients (aged $>18$ years) that were newly diagnosed with ALL at Alexandrovska University Hospital, Hematology Clinic, Sofia, Bulgaria during a 3-year period. Diagnosis of ALL was based on the French-American-British (FAB) classification system's morphological and cytochemical criteria, and on lymphoid immunophenotype. 


\section{Treatment}

Each patient underwent a standard induction regimen consisting of combination anthracycline, vincristine, prednisone, and cyclophosphamide, and prophylactic intrathecal methotrexate, methylprednisolone, and cytarabine, according to GETLALA-94 (Groupe d'Etude et de Traitement de la Leucémie Aiguë Lymphoblastique de l'Adulte) [15]. CR was followed by multidrug consolidation treatment, central nervous system prophylaxis, late intensification, and maintenance chemotherapy for 24 months.

\section{Definition of remission state}

CR was defined as $\leq 5 \%$ blast cells in normocellular or hypercellular bone marrow, a normal peripheral and differential blood count, and no extramedullary disease. Complete remission time was defined as the time from diagnosis to CR.

\section{Definition of resistant disease}

ALL was considered as resistant disease (RD) if CR was not achieved after 3 courses of induction therapy.

\section{Definition of overall survival}

Overall survival (OS) was the time of treatment onset to the time of death. Patients were censored for survival only at the date they were last known to be in complete remission or alive, respectively.

\section{Methods}

\section{Immunophenotyping}

Immunophenotyping was performed at Alexandrovska University Hospital, Allergology and Immunology Clinic. Leukemic cells obtained from fresh bone marrow or peripheral blood samples collected in EDTA-containing tubes were analyzed. Surface, cytoplasmic, and nuclear antigens were detected via a standard 2-color direct immunofluorescence assay using a broad panel of commercially available lymphoid and myeloid-associated monoclonal antibodies (MoAbs).

According to the European Group for Immunophenotyping of Leukemia (EGIL) [16], B-lineage acute leukemias were separated into the following 4 groups: pro-B-ALL (BI): CD19+, CD22+, cyCD79a+, CD10- cylg-, and sIg-; common B-ALL (BII): CD10+ (CALLA+), cylg-, sIg-; pre-B-ALL (BIII): CD10+/-, cylg +, and sIg-; mature B-ALL (BIV): sIg+. T-lineage ALL was characterized based on CD1a,
CD2, CD3, CD4, CD5, CD7, and CD8 cell marker expression. Myeloid markers (CD13, CD33, CD14, and CD15) were tested in most patients. For every antigen tested cell expression $>20 \%$ was considered a positive reaction.

\section{Conventional cytogenetics}

Conventional (routine) cytogenetic analysis was performed on material obtained from bone marrow aspiration. Bone marrow was treated with direct (without cell cultivation) and indirect methods (after $48 \mathrm{~h}$ of cultivation with 15\% fetal bovine serum at $37^{\circ} \mathrm{C}$ in RPMI) to obtain metaphases. Chromosomes were stained using the G-banding method and were analyzed via light microscopy and Icarus Metasystem software. Karyotypes were determined according to International System for Human Cytogenetic (ISHC) nomenclature [17]. The presence of $\geq 2$ metaphases with the same structural change, the same chromosome gain, or $\geq 3$ metaphases with deletion of the same chromosomes was considered as clonal aberration. At least 20 metaphases for each patient were carried out. Hypodiploid and hyperdiploid karyotypes were defined as having $<45$ and $>46$ chromosomes, respectively.

\section{Fluorescence in situ hybridization (FISH)}

FISH analysis was performed on cytogenetic preparations obtained from bone marrow cells. Direct labeling locus-specific probes (Vysis, Ltd.) were used for MLL gene rearrangements, bcr/abl gene fusion, and C-MYC rearrangements. Fluorescence signals were detected using fluorescence microscopy and ISIS Metasystem software. The size of genetically abnormal clones was determined after analyzing at least 100 successfully hybridized cells.

\section{Statistical methods}

The statistical variables tested for potential prognostic value were as follows: molecular-cytogenetic abnormalities, age, WBC count, hemoglobin value, platelet (PLT) count, immunologic subgroup, CR rates, frequency of $\mathrm{RD}$, early deaths, and survival times. Three- and 5-year survivals were estimated using the life tables' method. Kaplan-Meier [18] curves were constructed for CR time and survival; A Log rank test was used to compare these curves in both cytogenetic groups.

Comparison of quantitative variables between patient groups was performed using one-way analy- 
sis of variance. Comparison of qualitative data was performed using the chi-square test and t-test. All statistical analyses were 2 -sided. $\mathrm{P}$ values $<0.05$ were considered statistically significant.

Cytogenetic abnormalities were classified into 2 groups, as follows: 1) high risk: t(11q23)/MLL, $\mathrm{t}(9 ; 22) / \mathrm{bcr}-\mathrm{abl}$, hypodiploidy ( $<45$ chromosomes), $\mathrm{t}(1 ; 19), \mathrm{t}(8 \mathrm{q} 24) / \mathrm{C}-\mathrm{MYC}$, and complex karyotype; 2) standard risk: normal karyotype, hyperdiploidy, and other structural aberrations. The parameters were selected according to internationally accepted prognostic factors in ALL [7,11,19-21]. As a prognostic factor, cytogenetics was considered a binomial variable (high-risk group versus standard-risk group).

\section{Results}

Clinical and biological characteristics of the patients

Clinical and biological characteristics of the patients are shown in Table 1. The frequency of ALL increased with age; $61 \%$ of the patients were aged $>35$ years. More patients had B-cell leukemia (84.8\%) than T-cell leukemia $(15.2 \%, \mathrm{p}<0.001)$, and most had a WBC count $<30.10^{9} / \mathrm{L}(82 \%, \mathrm{p}<0.001)$.

\section{Cytogenetic data and correlations with clinical} and hematological features

Based on routine cytogenetic and FISH analysis, clonal chromosomal abnormalities were noted in 17

Table 1. Clinical and biological features of the adult patients with newly diagnosed ALL

\begin{tabular}{|c|c|c|c|c|c|}
\hline Characteristics & Parameters & n (\%) & CR n (\%) & $\begin{array}{c}\text { Time to CR } \\
\text { (months) }\end{array}$ & $\begin{array}{c}\text { OS } \\
\text { (months) }\end{array}$ \\
\hline \multicolumn{6}{|l|}{ Sex } \\
\hline & Female & $14(42.4 \%)$ & $8(57.1 \%)$ & $1.93(1.05-2.81)$ & $12.43(4.80-20.06)$ \\
\hline \multicolumn{6}{|l|}{ Age (years) } \\
\hline & $<35$ & $13(39 \%)$ & $11(84.6 \%)$ & $1.43(0.85-2.00)$ & $10.16(0.00-28.05)$ \\
\hline & $>35$ & $20(61 \%)$ & $11(55 \%)$ & $0.60(1.44-3.82)$ & $12.33(10.17-14.48)$ \\
\hline \multicolumn{6}{|l|}{ WBC $(\times 109 / \mathrm{L})$} \\
\hline & Median (range) & $16.5(1.7-300)$ & & & \\
\hline \multicolumn{6}{|c|}{ Immunophenotype } \\
\hline & B-lineage & $24(72.7 \%)$ & $15(62.5 \%)$ & $2.33(0.32-1.69)$ & $8.50(2.69-14.30)$ \\
\hline & T-lineage* & $5(15.2 \%)$ & $4(80 \%)$ & $2.33(0.76-0.83)$ & \\
\hline & Burkitt's type-B lineage & $4(12.1 \%)$ & $3(75 \%)$ & $1.36(0.29-0.78)$ & $10.86(0.00-27.03)$ \\
\hline \multicolumn{6}{|c|}{ Chromosomal pattern } \\
\hline & \multicolumn{5}{|l|}{ Cell ploidy abnormalities } \\
\hline & Normal diploid & $16(48.5 \%)$ & $9(56.3 \%)$ & $1.93(0.80-3.05)$ & $12.43(0.00-28.24)$ \\
\hline & Pseudodiploid (46, abnormal) & $13(49.4 \%)$ & $6(46.2 \%)$ & $1.40(0.32-2.47)$ & $10.16(3.73-16.59)$ \\
\hline & Normal diploidy & $16(48.5 \%)$ & $9(56.3 \%)$ & $1.93(0.80-3.05)$ & $12.43(0.00-28.24)$ \\
\hline
\end{tabular}

*OS in T-lineage ALL was not estimated because more than $50 \%$ of the patients died. Median OS is the time, which are gone through $50 \%$ of patients in the respectively group, CR- complete remission; OS- overall survival 
of the 33 ALL patients (52\%). Ploidy groups and structural changes were analyzed (Table 1). The ALL patients were divided into 2 risk groups (Table 2) according to molecular-cytogenetic aberrations, and basic biological and laboratory parameters at the time of diagnosis: high risk $(n=14,42.4 \%)$ and standard risk $(n=24,69.7 \%)$.

\section{Cell ploidy abnormalities}

Distribution of chromosomal ploidy anomalies in the patients was as follows: normal (46, normal): 16 cases (45.5\%); hyperdiploidy ( $>46)$ : 4 cases (12.1\%); pseudodiploidy (46, abnormal): 13 cases (49.4\%); hypodiploidy 0 cases (Table 1 ). Among the pseudodiploid karyotypes, changes were variable. The following chromosomes were involved with high frequency in balanced translocations: $4,7,8,9,11,14$, and 22. The short arms of chromosomes 4 and 12 were involved in deletion events. In 3 patients hyperdiploidy ( $>46$ ) was combined with structural aberrations $\mathrm{t}(9 ; 22)$, del $12 \mathrm{p}$, and del 14p. The incidence of hyperdiploid cell lines in individual patients ranged between $20 \%$ and $100 \%$ of the analyzed metaphases; chromosomes 8, 6, 12, and 21 were the most frequently involved.

\section{Structural abnormalities}

Structural changes were observed in 17 patients (52\%) with high-risk translocations $\mathrm{t}(9 ; 22)$ (q34; q11), $\mathrm{t}(8 \mathrm{q} 24), \mathrm{t}(11 \mathrm{q} 23)$, and $\mathrm{t}(1 ; 19)(\mathrm{q} 23 ; \mathrm{p} 13)$. The other structural abnormalities exhibited deletion of the short arm of chromosomes 4 and 12, and isochromosome 7 .

\section{Differences in $\mathrm{CR}$ rates}

The CR rate for the 33 patients was $67 \% ; 11$ patients did not achieve CR. The median time to achieve CR was 2.33 months (range: 1.47-3.19 months). Male gender, T-marker expression, age $<35$ years, and absence of high-risk translocations

Table 2. Pretreatment characteristics according to cytogenetic risk group

\begin{tabular}{|c|c|c|c|c|c|c|c|c|c|c|}
\hline Group & Total & \multicolumn{2}{|c|}{ Age (years)* } & \multicolumn{2}{|c|}{$\begin{array}{l}\text { WBC count } \\
\left(\times 10^{9} / \mathrm{L}\right)^{*}\end{array}$} & \multicolumn{2}{|c|}{$\mathrm{Hb}(\mathrm{g} / \mathrm{L})^{*}$} & $\begin{array}{l}\text { PLT count } \\
\left(\times 10^{9} / \mathrm{L}\right)^{*}\end{array}$ & $\begin{array}{l}\text { Phenotype } \\
\text { B-ALL }\end{array}$ & T-ALL \\
\hline Poor risk** & $14(42.4 \%)$ & \multicolumn{2}{|c|}{$43.5(25-63)$} & \multicolumn{2}{|c|}{$22.05(3.6-300)$} & \multicolumn{2}{|c|}{$92.0(49-161)$} & $61.0(5-147)$ & 14 & 0 \\
\hline $\mathrm{t}(9 ; 22) / \mathrm{bcr}-\mathrm{abl}$ & 5 & \multicolumn{2}{|c|}{$41.8(33-58)$} & \multicolumn{2}{|c|}{$9.2(3.6-20.1)$} & \multicolumn{2}{|c|}{$106(87-161)$} & $48(5-125)$ & 4 & 0 \\
\hline $\mathrm{t}(11 \mathrm{q} 23) / \mathrm{MLL}$ & 2 & \multicolumn{2}{|c|}{$25(25-25)$} & \multicolumn{2}{|c|}{$184.0(68-300.0)$} & \multicolumn{2}{|c|}{$95.5(68-123)$} & $76.5(23-130)$ & 2 & 0 \\
\hline $\mathrm{t}(8 \mathrm{q} 24) / \mathrm{C}-\mathrm{MYC}$ & 4 & \multicolumn{2}{|c|}{$48.5(25-63)$} & \multicolumn{2}{|c|}{$21.4(7.7-33.6)$} & \multicolumn{2}{|c|}{$84(67-106)$} & $93.7(8-147)$ & 4 & 0 \\
\hline $\mathrm{t}(1 ; 19) / \mathrm{E} 2 \mathrm{~A}-\mathrm{PBX} 1$ & 1 & \multicolumn{2}{|c|}{31} & \multicolumn{2}{|c|}{69.6} & \multicolumn{2}{|c|}{49} & 10 & 1 & 0 \\
\hline Complex karyotype & 2 & \multicolumn{2}{|c|}{$44(33-55)$} & \multicolumn{2}{|c|}{$16.1(3.6-28.6)$} & \multicolumn{2}{|c|}{$75(63-87)$} & $67.5(10-125)$ & 2 & 0 \\
\hline Standard risk** & $24(69.7 \%)$ & \multicolumn{2}{|c|}{$41.0(18-72)$} & \multicolumn{2}{|c|}{$12.95(1.7-300)$} & \multicolumn{2}{|c|}{$86.5(58-149)$} & $89(7-214)$ & 20 & 5 \\
\hline Normal karyotype & 16 & \multicolumn{2}{|c|}{$41.7(18-72)$} & \multicolumn{2}{|c|}{$12.5(1.7-87.3)$} & \multicolumn{2}{|c|}{$84.5(58-149)$} & $119.2(17-214)$ & 11 & 5 \\
\hline Hyperdiploidy & 4 & \multicolumn{2}{|c|}{$37.8(31-49)$} & \multicolumn{2}{|c|}{$13.2(3.6-23.0)$} & $92(86-$ & 136) & $49.0(7-125)$ & 4 & 0 \\
\hline $\operatorname{del}(4 p)$ & 2 & $52(4$ & $9-55)$ & $24.7(20.7$ & 7-28.6) & $72(63-$ & 82) & $9(8-10)$ & 2 & 0 \\
\hline $\mathrm{i}(7 \mathrm{q})$ & 2 & 37.5 & $25-50)$ & $153.4(6.8$ & 8-300) & $96.5(68$ & $-125)$ & $20(17-23)$ & 2 & 0 \\
\hline $\operatorname{del}(12 p)$ & 1 & & 9 & 23.0 & & 81 & & 8 & 1 & 0 \\
\hline $\begin{array}{l}\text { *Median and range in pare } \\
\text { WBC: White blood cells; } \\
\text { **Three patients had kary }\end{array}$ & $\begin{array}{l}\text { eses } \\
\text { nemoglobin; Pl } \\
\text { es with both h }\end{array}$ & $\begin{array}{l}\text { LT: platelets } \\
\text { high-risk and s }\end{array}$ & ndard-risk & abnormaliti & es and & include & hoth orou & & & \\
\hline Group & CR rates & Time to ach & ieve CR (m & months) & RD & tes or & & OS rate & & \\
\hline & (\%) & Median & $95 \% \mathrm{CI}$ & Sign. & $\begin{array}{r}\text { early } \\
\text { the first }\end{array}$ & $\begin{array}{l}\text { eath in } \\
3 \text { months }\end{array}$ & $\begin{array}{c}\text { Median } \\
\text { (months) }\end{array}$ & 95\% CI Sign. & $\begin{array}{c}\begin{array}{c}\text { 3-year } \\
\text { survival }\end{array} \\
\end{array}$ & $\begin{array}{c}\text { 5-year } \\
\text { survival }\end{array}$ \\
\hline High risk $(n=14)$ & $9(41 \%)$ & 1.97 & $1.30-3.36$ & 0.515 & & 3\%) & 9.85 & $3.89-16.43 \quad .015$ & $10 \%$ & $10 \%$ \\
\hline Standard risk $(n=24)$ & $13(59 \%)$ & 2.33 & $0.92-3.01$ & & & $3 \%)$ & 18.00 & $1.11-25.23$ & $29 \%$ & $24 \%$ \\
\hline Total $(n=33)$ & $22(100 \%)$ & 2.33 & $1.47-3.19$ & & 14 & 42\%) & 13.93 & $9.27-15.39$ & $19.5 \%$ & $17 \%$ \\
\hline
\end{tabular}

CR- complete remission; CI- confidential interval; RD- resistant disease; OS- overall survival 
might have contributed to the high CR rate (Table 1). The CR rate was 64\% in the high-risk group and 54\% in the standard-risk group $(p=0.755)$ (Table 3$)$. Patients with $\mathrm{t}(1 ; 19)$, i(7q), and del (12p) had the highest CR rates (Table 4), but the number of patients with these aberrations was very low- 5 of 33 cases.

Female gender, age >35 years, Burkitt's-type ALL, and pseudodiploidy were associated with the shortest time to first CR (Table 1). The median time to achieve CR was not statistically different between the 2 groups 2.3 months in the standard-risk group and 1.9 months in the high-risk group $(p=0.515)$ (Table 3$)$. Patients with $\mathrm{t}(9 ; 22) /$ bcr-abl had the longest time to $\mathrm{CR}$ and the highest RD rate (Table 4).

\section{Differences between 3-year, 5-year, and}

overall survival

Patients with hyperdiploidy karyotypes, a low WBC count, random cytogenetic aberrations, and females had the longest OS (Table 1). As indicated in Table 3 and the Figure, median OS was significantly shorter in the high-risk group (9.85 months) than in the standardrisk group (18 months) $(p=0.015)$. The estimated

Table 4. Estimated CR rates, and time to first CR or RD according to molecular-cytogenetic abnormalities

\begin{tabular}{llccc}
\hline Groups & $\begin{array}{l}\text { Cytogenetic } \\
\text { aberrations }\end{array}$ & $\begin{array}{c}\text { CR rates } \\
\text { (\%) }\end{array}$ & $\begin{array}{c}\text { Time to } \\
\text { achieve } \\
\text { CR } \\
\text { (months) }\end{array}$ & $\begin{array}{c}\text { RD rate or } \\
\text { early death } \\
\text { in the first } \\
\text { 3 months }\end{array}$ \\
\hline High risk & $\mathrm{t}(9 ; 22) / \mathrm{bcr}-\mathrm{abl}$ & $60 \%$ & 2.73 & $60 \%$ \\
$(\mathrm{n}=14)$ & $\mathrm{t}(11 \mathrm{q} 23) / \mathrm{MLL}$ & $50 \%$ & 1.0 & $50 \%$ \\
& $\mathrm{t}(8 \mathrm{q} 24) / \mathrm{C}-\mathrm{MYC}$ & $75 \%$ & 1.9 & $50 \%$ \\
& $\mathrm{t}(1 ; 19) / \mathrm{E} 2 \mathrm{~A}-\mathrm{PBX} 1$ & $100 \%$ & 1.4 & $0 \%$ \\
& complex karyotype & $50 \%$ & 2.5 & $50 \%$ \\
Standard & normal karyotype & $60 \%$ & 1.7 & $40 \%$ \\
risk (n=24) & hyperdiploidy & $50 \%$ & 2.25 & $50 \%$ \\
& del (4p) & $50 \%$ & 2.57 & $50 \%$ \\
& $\mathrm{i}(7 \mathrm{q})$ & $100 \%$ & 1 & $0 \%$ \\
& del(12p) & $100 \%$ & 2.5 & $0 \%$ \\
\hline
\end{tabular}

CR- complete remission; RD- resistant disease 3-year survival was $19.5 \%$ for all patients; $10 \%$ for the high-risk group vs. $29 \%$ for the standard risk group $(\mathrm{p}=0.001)$. In all, $17 \%$ of the patients had 5 -year survival; $10 \%$ in the high-risk group and $24 \%$ in the standard risk group $(p=0.005)$. A significant difference in OS was observed between the patients with and without CR $(p=0.001)$ (Table 5).

A comparison of the frequency and types of molecular-cytogenetic aberrations in the immunological subgroups is presented in Table 6 . The frequency of Â-lineage ALL (28 cases, $84.8 \%$ ) was statistically higher than T-lineage ALL (5 cases, 15.2\%) $(p<0.001)$. Among the B-ALL patients, $60.7 \%$ were common B-ALL (BII), 17.9\% were pro-B ALL (BI), $17.9 \%$ were mature B-ALL (B-IV), and $3.5 \%$ were pre-B ALL (B-III).

\section{Discussion}

It has been reported that cytogenetics is the most important prognostic factor in adult ALL patients [12,22-25]. Based on their results, these researchers were able to classify patients into standard-, intermediate-, and high-risk groups with significant differences in survival.

The present study compared patient characteristics, molecular-cytogenetic data, CR, and OS in a group of 33 newly diagnosed adult ALL patients that were treated with the standard adult ALL protocol. In all, $42.4 \%$ of the patients were included in the high-risk group. All the patients were aged $>35$ years (except MLL $(+)$ patients with a median age of 25 years, $\mathrm{p}=0.02$ ). The median time to achieve CR differed insignificantly between the 2 molecularcytogenetic groups. Interestingly, time to $\mathrm{CR}$ was shorter in the high-risk group than in the standardrisk group.

The Philadelphia ( $\mathrm{Ph}$ ) chromosome was the most frequent karyotypic aberration in the high-risk group (35.7\% in the high-risk group versus $15.15 \%$ in all 33 ALL patients), which is higher than previously reported (15\%-30\%) [7,13,19,26-30]. Our observa-

Table 5. OS (months) according to remission status

\begin{tabular}{lcccccc}
\hline Status remission & Number & Percents & \multicolumn{3}{c}{ OS (months) } \\
\cline { 4 - 7 } & & & Median & Std. Error & 95\% CI \\
\hline Patients without CR & 11 & $33.3 \%$ & 4.33 & 1.96 & 0.49 \\
Patients with CR & 22 & $66.7 \%$ & 13.17 & 8.06 & 0.00 & 28.96 \\
Overall & 33 & $100 \%$ & 12.33 & 1.56 & 9.27 \\
\hline
\end{tabular}

OS- Overall survival, CI- confidential interval 
Table 6. Cytogenetic and laboratory data according to phenotype Pro Common Pre Mature T-ALL

B-ALL B-ALL B-ALL B-ALL

\begin{tabular}{lccccc}
\hline Total patients & 5 & 17 & 2 & 4 & 5 \\
\hline Normal karyotype & 3 & 8 & 0 & 1 & 5 \\
\hline Hyperdiploidy & 2 & 1 & 1 & 0 & 0 \\
\hline Translocations & 1 & 5 & 2 & 3 & 0 \\
\hline Deletions & 1 & 4 & 0 & 0 & 0 \\
\hline Complex karyotype & 0 & 1 & 1 & 0 & 0 \\
\hline Age* (years) & 44.6 & 40.7 & 27.5 & 49 & 36.8 \\
\hline WBC* $\left(\times 10^{9} / \mathrm{L}\right)$ & 20.7 & 67.5 & 13.8 & 36.8 & 24.0 \\
\hline Hb* $^{*}$ (g) & 80.4 & 88.0 & 96.5 & 74.6 & 83.4 \\
\hline PLT $^{*}\left(\times 10^{9} / \mathrm{L}\right)$ & 66.8 & 79.5 & 66.5 & 67.5 & 112 \\
\hline $\mathrm{CR}_{\text {rate }(\%)}$ & $40 \%$ & $64.70 \%$ & $100 \%$ & $75 \%$ & $80 \%$ \\
\hline
\end{tabular}

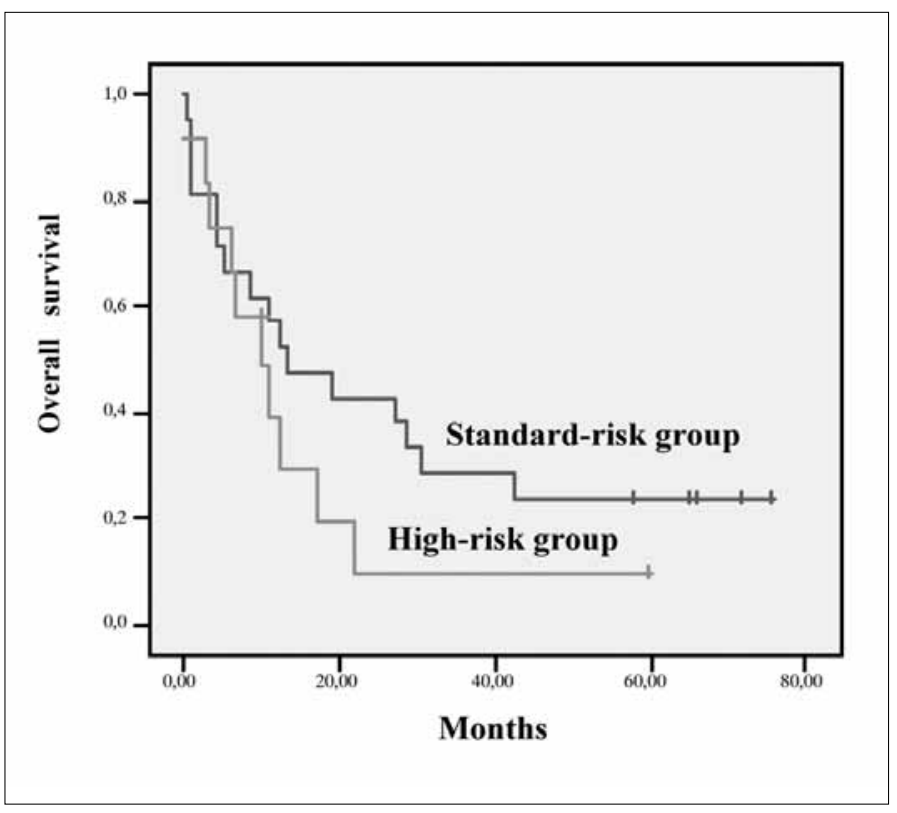

Figure 1. Estimated OS (months) according to cytogenetic risk group. Standard-risk group: normal karyotype, hyperdiploidy, and other structural aberrations; high-risk group: $\mathrm{t}(11 \mathrm{q} 23), \mathrm{t}(9 ; 22)$, $\mathrm{t}(1 ; 19), \mathrm{t}(8 ; 14)$, and complex karyotype

tion pointed for variable immunophenotypes in $\mathrm{Ph}(+) \mathrm{ALL}$, without any apparent connection to a specific phenotype. Leukemic blasts in $\mathrm{Ph}(+)$ ALL expressed B-lineage-specific markers and aberrant myeloid markers in 3 of the 4 cases. According to Tabernero et al., [31] the frequency of myeloid coexpression in $\mathrm{Ph}(+)$ ALL is higher than that in $\mathrm{Ph}(-)$ ALL. High myeloid expression of CD13, CD33, and CD15 in 75\% of lymphoblasts in Ph(-) ALL has been observed. In the present study patients with $t(9 ; 22)$ and/or bcr/abl rearrangements had a $60 \% \mathrm{CR}$ rate and longer time to CR (2.73 months) than other cases in the high-risk group.
In all, $14.3 \%$ of the high-risk patients and $6.1 \%$ of all the patients in the present study had $t(4 ; 11)$ (q21;q23) translocation and/or rearrangement of the MLL gene. Most leukemic blasts with this translocation had a pro-B-ALL or CALLA $(+)$ phenotype. One MLL(+) patient expressed myeloid antigens CD33 and cyCD13 without fulfilling the criteria for biphenotypic leukemia. The lowest median age was in patients with 11q23/MLL and a high correlation index $(r=0.999)$ of the translocation with a high leukocyte level (median WBC count: $95.5 \times 10^{9} / \mathrm{L}$ ). CR was achieved in 1 of the MLL cases. The time to CR was the shortest (1 month), despite the presence of markers of poor prognosis (high WBC count and myeloid co-expression). These findings highlight the difficulty in confirming the independent prognostic importance of relatively small cytogenetic subgroups that are strongly correlated with other risk factors, such as the WBC count and age $[20,23,32-34]$. In the present study the frequency of $8 q 24$ translocations and/or rearrangements of the C-MYC proto-oncogene was high $28.6 \%$ in the highrisk group and $12 \%$ in all 33 patients. Translocations (8q24)/C-MYC are the molecular-cytogenetic label of Burkitt's leukemia/lymphoma [7,21,22,34,35]. Interestingly, only 3 of the 33 patients in the present study had typical mature B-cell phenotype-positive CD19, CD20, CD10, surface IgM, and CD 79a, and negative CD5, CD23, and TdT. Among the pre-B-ALL patients, involvement of the MYC gene was confirmed in 1 . This is not the first time that $t(8 ; 14)$ has been reported beyond the context of mature B-ALL [36]. The presence of $\mathrm{t}(8 \mathrm{q} 24) / \mathrm{C}-\mathrm{MYC}$ is associated with poor prognosis and a low $\mathrm{CR}$ rate [7,23,33,35,37]. We observed a high CR rate (75\%) in the present study, but $50 \%$ of $8 \mathrm{q} 24$ cases had RD or early death in the 3 months following diagnosis.

Translocation $\mathrm{t}(1 ; 19)(\mathrm{q} 23 ; \mathrm{p} 13)$ was observed in 1 (2.9\%) of the ALL patients in the present study; the patient had a high WBC count $(69.6 \times 109 / \mathrm{L})$, very low hemoglobin $(49 \mathrm{~g} / \mathrm{L})$, and low PLT count $\left(10 \times 10^{9} / \mathrm{L}\right)$. This translocation is a rare cytogenetic aberration in adult ALL and correlates with immature B-lineage phenotypes, especially pro-B-ALL $[7,32,37,38]$. The patient's leukemic blasts presented as non-typical for $t(1 ; 19)$ more mature immunophenotype with expression of CD10 (CALLA ) antigens. CR in this $t(1 ; 19)(+)$ patient was achieved rapidly and without therapy resistance 1 month after starting the initial treatment.

Complex chromosomal abnormalities are rare in 
adult ALL patients [7,8,10,12,39]. Using cytogenetic methods we characterized complex karyotypes in 2 of the 33 cases $(6.1 \%)$; among them, only 1 achieved hematological $\mathrm{CR}$, despite the presence of $\mathrm{Ph}(+)$ blasts in multiple chromosomal aberrations. Among the 33 patients in the present study, 24 (73\%) were in the standard-risk group, which had the highest prevalence of normal karyotypes (62.5\%). This frequency correlates with previously published data $[12,22,24]$. Patients in the standard-risk group had a higher rate of first CR ( $59 \%$ vs. $41 \%$ in high-risk group, $\mathrm{p}=0.775$ ), but the time to $\mathrm{CR}$ was longer ( 2.33 vs. 1.9 months, $\mathrm{p}=0.515$ ). The standard-risk group had a lower RD and early death rates (33\%) than the high-risk group $(43 \%, \mathrm{p}=0.05)$. Studies of survival in adult ALL patients have consistently shown that those with standard-risk cytogenetic aberrations survive longer than do patients with poor prognostic abnormalities. In the present study median OS in standard-risk patients was significantly longer (18 months vs. 9.85 months, $\mathrm{p}=0.02$ ).

To date, analysis of cytogenetic aberration changes in cell ploidy in adult ALL patients are rare, but are most often combined with structural abnormalities (pseudodiploid (46, abnormal). Most likely they have no clear self-diagnostic or prognostic significance, as in pediatric ALL patients [10,11,35,40]. Poor prognosis associated with pseudodiploidy is likely a reflection of structural rearrangements and other unfavorable features. CR was achieved in patients with the hyperdiploidy karyotype only among those without $\mathrm{t}(9 ; 22)$ or bcr/abl rearrangements.

Among the structural aberrations in adult ALL, deletions and isochromosomes were the second most frequent changes after translocations [7,11,33]. These chromosome abnormalities are usually classified as miscellaneous or random changes with an unclear disease prognosis [12,22,23] Inactivation of tumor suppressor genes located in regions $4 p, 12 p$, and $7 \mathrm{q}$ often leads to the start of a leukemic process $[7,11,33,41]$. In all but 1 of the patients in the present study with a combination of $\operatorname{del}(4 \mathrm{p})$ and $\mathrm{t}(4 ; 11)$ deletions presented as single cytogenetic aberrations. Despite having unfavorable pretreatment laboratory characteristics (age $>35$ years and low PLT count), the patients with miscellaneous abnormalities had a better CR rate than the patients with nonrandom chromosome changes.

Distribution of immunophenotypes in the pres- ent study was similar to that previously published [41-43]. Numerical and structural translocations were more frequent in the mature B-ALL (75\% of B IV cases) and pre-B-ALL (100\%) patients. A lot of them were with poor prognostic significance $\mathrm{t}(9 ; 22) / \mathrm{bcr}-\mathrm{abl}, \mathrm{t}(8 \mathrm{q} 14) / \mathrm{C}-\mathrm{MYC}$ and complex karyotype. The high CR rate in these patients $(100 \%$ in pre-B-ALL and $75 \%$ in mature B-ALL) show that molecular-cytogenetic abnormalities were important, but not determinative of the achievement of the first CR, and that pretreatment laboratory and biological characteristics affected the management of the disease. The most common lymphoblast leukemia among the presented patients was common B-ALL (51.5\%), which was associated with a high WBC count at presentation and high-risk cytogenetic aberrations. The common B-ALL patients had a higher incidence of $\mathrm{Ph} / \mathrm{bcr}-\mathrm{abl}(+)$ leukemia $(24 \%$ of the common B-ALL cases) and a lower CR rate (64.7\%) than the mature B-ALL patients. The pro-BALL (BI) patients had the lowest CR rate (40\%), despite the presence of standard-risk cytogenetic changes. It is likely that the immunologically immature features of leukemic blasts were associated with poor disease outcome.

In all, 25\%-30\% of adult ALL cases have T-lineage ALL [42,44-46]. We studied a small group of T-ALL patients (15.2\% of all ALL cases) and observed a higher CR rate in the T-ALL patients than in the B-ALL and Burkitt's-type leukemia patients. The CR rate in the adult ALL patients appeared to be influenced positively by the absence of high-risk translocations and favorable pretreatment laboratory characteristics.

\section{Conclusion}

The present study shows that karyotype was an independent prognostic factor in the adult ALL patients for predicting OS following intensive treatment regimens, and that laboratory and biologic features (age, and WBC and PLT counts), and immunophenotype greatly influenced CR and disease outcome.

This small cohort of adult ALL cases and the high-quality cytogenetic data obtained demonstrate the value of cytogenetics for identifying patients with high and low risk of treatment failure. Future randomized clinical trials on adult ALL can and should use cytogenetic data to stratify patients into appropriate risk groups, so as to ensure they receive the most suitable therapy.

Additional cytogenetic and molecular genetic 
studies of adult ALL are urgently required to further characterize this disease, thereby increasing the number of patients than can benefit from alternative treatment strategies.

\section{Acknowledgement}

We extend our gratitude to the International Scientific Committee for awarding this report the First Prize at the 2010 Balkan Awards for Clinical Laboratory Research, sponsored by BioSystems.

\section{Conflict of interest statement}

The authors of this paper have no conflicts of interest, including specific financial interests, relationships, and/or affiliations relevant to the subject matter or materials included.

\section{References}

1. Demczuk S. Oncogenes: a review ot their clinical application. Crit Rev oncol Hematol 1991;11:209-39.

2. Metcalf D. The molecular control of cell division, differentiation commitment and maturation in haemopoietic cells. Nature 1989;339:27-30.

3. Prasad KN, Hohland AR, Nahreini P, Cole WC, Hohland P, Kuman B, Prasad KC. Differentiation on genes: are they primary targets for human carcinogenesis? Exp Biom Med 2001;226:805-13.

4. Lee J, Sait SN, Wetzler M. Characterization of dendriticlike cells derived from $\mathrm{t}(9 ; 22)$ acute lymphoblastic leukemia blasts. Int Immunol 2004;16:1377-89.

5. Hangaishi A, Ogawa S, Imamura N, Miyawaki S, Miura Y, Uike N, Shimazaki C, Emi N, Takeyama K, Hirosawa S, Kamada N, Kobayashi Y, Takemoto Y, Kitani T, Toyama $\mathrm{K}$, Ohtake S, Yazaki Y, Ueda R, Hirai H. Inactivation of multiple tumor-suppressor genes involved in negative regulation of the cell cycle, MTS1/p16INK4A/CDKN2, MTS2/p15INK4B, p53, and Rb genes in primary lymphoid malignancies. Blood 1996;87:4949-58.

6. Bloomfield CD, Secker-Walker LM, Goldman AI, Van Den Berghe H, de la Chapelle A, Ruutu T, Alimena G, Garson OM, Golomb HM, Rowley JD, et al. Six-year followup of the clinical significance of karyotype in acute lymphoblastic leukemia. Cancer Genet Cytogenet 1989;40:171-85.

7. Hoelzer D, Arnold R, Bartram CR, Bohme A, Freund M, Ganser A, Kneba M, Lipp T, Ludwig WD, Maschmeyer G, Rieder H, Thiel E, Messerer D, Weiss A, Gokbuget N. Acute lymphatic leukemia in the adult. Diagnosis, risk groups and therapy. Internist (Berl) 2002;43:1212-6.

8. Hoelzer D, Thiel E, Loffler H, Buchner T, Ganser A, Heil G, Koch P, Freund M, Diedrich H, Ruhl H. Prognostic factors in a multicenter study for treatment of acute lymphoblastic leukemia in adults. Blood 1988;71:123-31.

9. Larson RA. Management of acute lymphoblastic leukemia in older patients. Semin Hematol 2006;43:126-33.

10. Ramos MM, Palacios JL, López JM, Rodríguez MG,
Izquierdo AM, Miranda EB. Karyotype and prognosis in adult Spanish acute lymphoblastic leukemia. Haematologica 2001;86:438-9.

11. Faderl S, Kantariian HM, Talpaz M, Estrov Z. Clinical significance of cytogenetic abnormalities in adult acute lymphoblastic leukemia. Blood 1998;91:3995-4019.

12. Moorman AV, Harrison CJ, Buck GN, Richards SM, Secker-Walker LM, Martineau M, Vance GH,Cherry AM, Higgins RR, Fielding AK, Foroni L. Karyotype is an independent prognostic factor in adult acute lymphoblastic leukemia (ALL): analysis of cytogenetic data from patients treated on the Medical Research Council (MRC) UKALLXII/Eastern Cooperative Oncology Group(ECOG) 2993 trial. Blood 2007;109:3189-97.

13. Westbrook CA, Hooberman AL, Spino C, Dodge RK, Larson RA, Davey F, Wurster- Hill DH, Sobol RE, Schiffer C, Bloomfield CD. Clinical significance of the BCR-ABL fusion gene in adult acute lymphoblastic leukemia: A Cancer and Leukemia Group B Study (8762). Blood 1992;80:2983-90.

14. Hoelzer D, Gokbuget N. New approaches to acute lymphoblastic leukemia in adults: where do we go? Semin Oncol 2000;27:540-59.

15. Thomas X, Boiron JM, Huguet F, Dombret $\mathrm{H}$, Bradstock K, Vey N, Kovacsovics T, Delannoy A, Fegueux N, Fenaux P, Stamatoullas A, Vernant JP, Tournilhac O, Buzyn A, Reman O, Charrin C, Boucheix C, Gabert J, Lhéritier $\mathrm{V}$, Fiere D. Outcome of treatment in adults with acute lymphoblastic leukemia: analysis of the LALA-94 trial. J Clin Oncol 2004;22:4075-86.

16. Bene MC, Castoldi G, Knapp W, Ludwig WD, Matutes E, Orfao A, van't Veer MB. Proposals for the immunological classification of acute leukemias. European Group for the Immunological Characterization of Leukemias (EGIL). Leukemia. 1995;9:1783-86.

17. Shaffer LG, Tommerup N, editors. An International System for Human Cytogenetic Nomenclature. Karger 2005.

18. Kaplan E, Meier P. Nonparametric estimation from incomplete observations. J Am Stat Assoc 1958;53:457-81.

19. Thomas DA. Philadelphia Chromosome-Positive Acute Lymphocytic Leukemia: A New Era of Challenges. Hematology Am Soc Hematol Educ Program. 2007;435-43.

20. Gökbuget N, Hoelzer D. Recent approaches in acute lymphoblastic leukemia in adults. Rev Clin Exp Hematol 2002;6:114-41.

21. Pui CH, Evans WE. Acute lymphoblastic leukemia. N Engl J Med 1998;339:605-15.

22. Wetzler M, Dodge RK, Mrózek K, Carroll AJ, Tantravahi R, Block AW, Pettenati MJ, Le Beau, MM, Frankel SR, Stewart CC, Szatrowski, Schiffer CA, Larson RA, CD Bloomfield. Prospective karyotype analysis in adult acute lymphoblastic leukemia: The Cancer and Leukemia Group B Experience. Blood 1999;93:3983-93.

23. Cytogenetic abnormalities in adult acute lymphoblastic leukemia: correlations with hematologic findings and outcome. A Collaborative Study of the Group Français de Cytogénétique Hématologique. Blood 1996;87:3135-42.

24. Secker-Walker LM, Prentice HG, Durrant J, Richards, Hall E, Harrison G. Cytogenetics adds independent prognostic information in adults with acute lympho- 
blastic leukemia on MRC trial UKALL XA. Br J Haematol 1997;96:601-10.

25. Mancini M, Scappaticci D, Cimino G, Nanni M, Derme V, Elia L, Tafuri A, Vignetti M, Vitale A, Cuneo A, Castoldi G, Saglio G, Pane F, Mecucci C, Camera A, Specchia G, Tedeschi A, Di Raimondo F, Fioritoni G, Fabbiano F, Marmont F, Ferrara F, Cascavilla N, Todeschini G, Nobile F, Kropp MG, Leoni P, Tabilio A, Luppi M, Annino L, Mandelli F, Foà R. A comprehensive genetic classification of adult acute lymphoblastic leukemia (ALL): analysis of the GIMEMA 0496 protocol. Blood 2005; 105:3434-41. [CrossRef]

26. Yanada M, Takeuchi J, Sugiura I, Akiyama H, Usui N, Yagasaki F, Nishii K, Ueda Y, Takeuchi M, Miyawaki S, Maruta A, Narimatsu H, Miyazaki Y, Ohtake S, Jinnai I, Matsuo K, Naoe T, Ohno R; Japan Adult Leukemia Study Group. Karyotype at diagnosis is the major prognostic factor predicting relapse-free survival for patients with Philadelphia chromosome-positive acute lymphoblastic leukemia treated with imatinib-combined chemotherapy. Haematologica 2008;93:287-90.

27. Pane F, Intrieri M, Quintarelli C, Izzo B,Muccioli GC, Salvatore F. BCR/ABL genes and leukemic phenotype: from molecular mechanisms to clinical correlations. Oncogene 2002;21:8652-67.

28. Nashed AL,Rao KW,Gulley ML. Clinical applications of BCR-ABL molecular testing in acute leukemia. J Mol Diagn 2003;5:63-72.

29. Faderl S, O'Brien S, Pui C-H, Stock W, Wetzler M, Hoelzer D, Kantarjian H. Adult acute lymphoblastic leukemia concepts and strategies. Cancer 2010;116:1165-76.

30. Huret JL, Minor SL, Dorkeld F, Dessen P, Bernheim A. Atlas of genetics and cytogenetics in oncology and hematology, an interactive database. T $(9 ; 22)$ (q34; q11). Nucleic Acids Res 2000;28:349-51.

31. Tabernero MD, Bortoluci AM, Alaejos I, Lopez-Berges MC, Rasillo A, Garcia-Sanz R, Garcia M, Sayagues JM, Gonzalez M, Mateo G, San Miguel JF, Orfao A. Adult precursor B-ALL with BCR/ABL gene rearrangements displays a unique immunophenotype based on the pattern of CD10, CD34, CD13, and CD38 expresssion. Leukemia. 2001;5:406-14.

32. Huret JL. 11q23 rearrangements in leukaemia. Atlas Genet Cytogenet Oncol Haematol 2003. http://www. infobiogen.fr/services/chromcancer/ Anomalies/ 11q23ID1030.html.

33. Pullarkat V, Slovak ML, Kopecky KJ, Forman SJ, Appelbaum FR. Impact of cytogenetics on the outcome of adult acute lymphoblastic leukemia: results of Southwest Oncology Group 9400 study. Blood
2008;111:2563-72.

34. Abe R, Sandberg AA. Significance of abnormalities involving chromosomal segment 11q22-25 in acute leukemia. Cancer Genet Cytogenet 1984;13:121-7.

35. Levitt L, Lin R. Biology and treatment of adult acute lymphoblastic leukemia. West j Med 1996;164:143-55.

36. Bellan C, Lazzi S, De Falco G, Nyongo A, Giordano A, Leoncini L. Burkitt's lymphoma: new insights into molecular pathogenesis. J Clin Pathol 2003;56:188-92.

37. Mitelman Database of Chromosome Aberrations and Gene Fusions in Cancer . Mitelman F, Johansson B and Mertens F (Eds.), 2010. Available at: http://cgap.nci.nih. gov/Chromosomes/Mitelman.

38. Nourse J, Mellentin JD, Galili N, Wilkinson J, Stanbridge E, Smith SD, Cleary ML. Chromosomal translocation $t(1 ; 19)$ results in synthesis of a homeobox fusion mRNA that codes for a potential chimeric transcription factor. Cell 1990;60:535-45.

39. Ludwig WD, Rieder H, Bartram CR, Heinze B, Schwartz S, Gassmann W, Loffler H, Hossfeld D, Heil G, Handt S, Heyll A, Diedrich H, Fischer K, Weiss A, Volkers B, Aydemir U, Fonatsch C, Gokbuget N, Thiel E, Hoelzer D. Immunophenotypic and genotypic features, clinical characteristics, and treatment outcome of adult pro-B acute lymphoblastic leukemia: results of the German Multicenter Trials GMALL 03/87 and 04/89. Blood 1998;92:1898-909.

40. Pui CH, Relling MV, Downing JR. Acute lymphoblastic leukemia. N Engl J Med 2004; 350:1535-48. [CrossRef]

41. Brozek I, Babinska M, Kardas I, Wozniak A, Balcerska A, Hellmann A, Limon J. Cytogenetic analysis and clinical significance of chromosome 7 aberrations in acute leukaemia. J Appl Genet 2003;44:401-12.

42. Jennings $\mathrm{CD}$, Foon KA. Recent àdvances in flow cytometry: application to the diagnosis of hematologic malignancy. Blood 1997;90:2863-92.

43. Gill PS, Meyer PR, Pavlova Z, Levine AM.B cell acute lymphocytic leukemia in adults-Clinical, morphologic, and immunologic findings. J Clin Oncol 1986;4:737-43.

44. Drexler HG, Thiel E. Ludwig WD. Review of the incidence and clinical relevance of myeloid antigen-positive acute lymphoblastic leukemia. Leukemia 1991;5:637-45.

45. Raimondi SC. T-lineage acute lymphoblastic leukemia (T-ALL).AtlasGenetCytogenetOncolHaematol.2007;URL: http://AtlasGeneticsOncology.org/Anomalies/ TALLID1374.html

46. Hoelzer D, Gökbuget N, Ottmann O, Pui CH, Relling MV, Appelbaum FR, van Dongen JM, Szczepanski T. Acute Lymphoblastic Leukemia. Hematology 2002;2:162-92. 